\title{
GIS Water Quality Simulation Study: Chinchuba Watershed
}

\author{
Gianna M. Cothren \\ Department of Civil and Environmental Engineering, College of Engineering, University of New Orleans, New Orleans, LA, USA \\ Email: GCothren@uno.edu
}

How to cite this paper: Cothren, G.M. (2019) GIS Water Quality Simulation Study: Chinchuba Watershed. Journal of Geographic Information System, 11, 405-410. https://doi.org/10.4236/jgis.2019.113025

Received: July 31, 2018

Accepted: June 27, 2019

Published: June 30, 2019

Copyright $\odot 2019$ by author(s) and Scientific Research Publishing Inc. This work is licensed under the Creative Commons Attribution International License (CC BY 4.0).

http://creativecommons.org/licenses/by/4.0/

\begin{abstract}
The purpose of the study is to enhance the watershed management for St. Tammany parish, LA through development of a model that will account for water quality impacts. Bayou Chinchuba in St. Tammany parish Louisiana is selected for this water quality model. Developed with HSPF (Hydrologic Simulation Program in Fortran), the model is used to calculate $\mathrm{NO}_{3}, \mathrm{PO}_{4}$, and BOD loading rates for varying scenarios of land use development. GIS tools are used to determine, visualize, and compare the total loads generated within sub-basins of the watershed based on the model simulation results. With the GIS calculation of $\mathrm{NO}_{3}, \mathrm{PO}_{4}$, and $\mathrm{BOD}$ total load and visualization enhancement, this tool simulates existing conditions and compares the water quality impact to 2020 expectation values.
\end{abstract}

\section{Keywords \\ GIS, HSPF, Water Quality Simulation, Landuse}

\section{Introduction}

An HSPF (Hydrologic Simulation Program in Fortran) model has been developed that can be used to visualize the impact on water quality with changes in land use. The study area selected for this project is Bayou Chinchuba which is 5780 acres consisting of undeveloped land, commercial property, and residential development [1]. Part of the watershed is within the City of Mandeville. The main channel of Bayou Chinchuba is 7.5 miles in length and discharges to Lake Ponchartrain. The lower part of the watershed, nearest Lake Pontchartrain, has had rapid residential development over the past 10 years [1]. The upper end of the watershed is less developed, but overall development patterns in St Tammany parish suggest that this area will see development in the immediate future [1]. Without a comprehensive management approach to future land development 
that takes into account water quality, a decrease in the beneficial uses of this waterway could occur. The Bayou Chinchuba water quality model has been developed to be used as a guide in making decisions concerning land development within the existing system. This project will focus on using GIS to calculate and display water quality loading rates within sub basins of the Bayou Chinchuba watershed.

\section{Methodology}

The HSPF model [2] uses a GIS database for development of the model and, through this project, the display of the water quality results. The shape file of the Chinchuba watershed from a previous study is imported and associated with the National Hydrography Dataset (NHD) stream database, soils, and land use (Figure 1). The sub-basins within the Chinchuba watershed are manually delineated and clipped to the watershed boundary. The EPA BASIN's networking tool is used to create outlets, sub-basins, and steams for the HSPF [3]. The model simulation is calibrated for flow, and then the water quality components are added including parameters for $\mathrm{NO}_{3}, \mathrm{PO}_{4}$, and $\mathrm{BOD}$ [4]. Each is calibrated for flow and then water quality using existing data.

A base case is considered the current state of the watershed with regard to landuse distribution and topographical data that are used to build the model

\section{Chinchuba Watershed Water Quality Study}
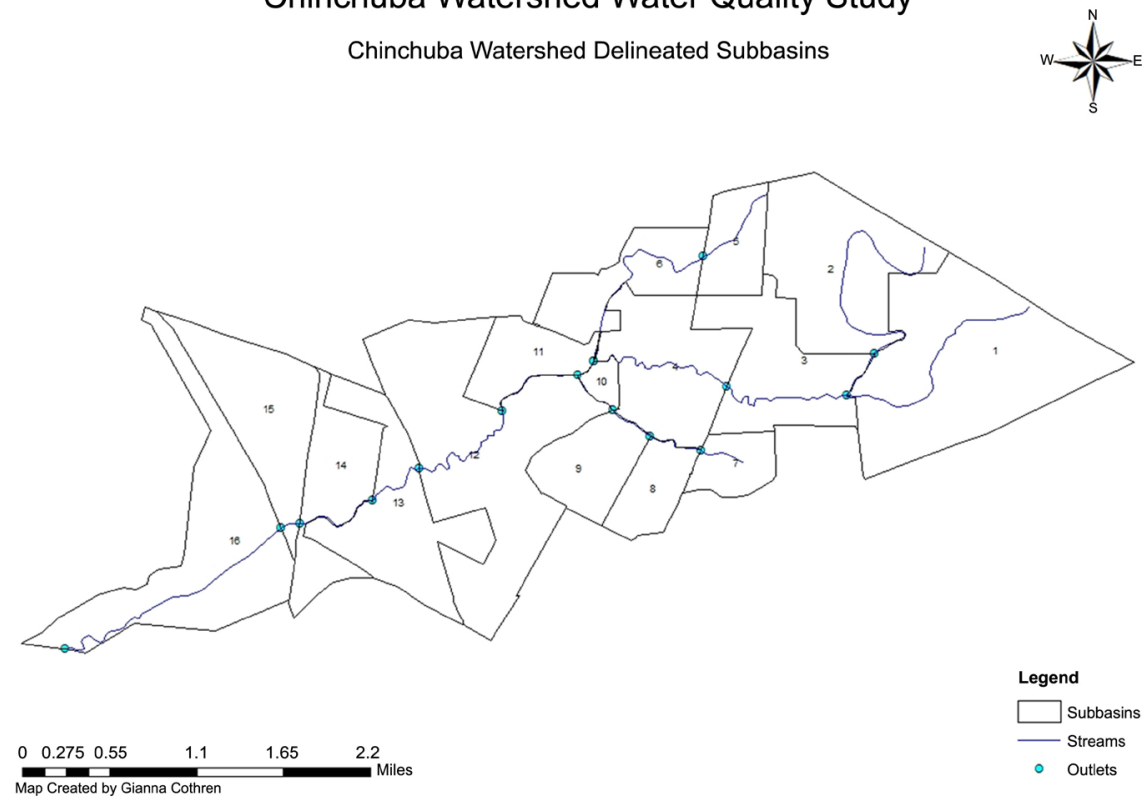

Figure 1. Chinchuba Watershed delineated shape file with Hydrography Dataset (NHD) stream database and outlets (USGS) along Bayou Chinchuba, St. Tammany parish Louisiana imported to ArcGIS 10.3. Source: United States Geological Survey (2008). National Hydrography Dataset (NHD)_USGS National Map Downloadable Data Collection. Available from USGS website:

https://catalog.data.gov/dataset/usgs-national-hydrography-dataset-nhd-downloadable-d ata-collection-national-geospatial-data-as. 
(Table 1). The future development scenario using the St. Tammany 2025 land use development plan is created (Figure 2). The greatest change in landuse from existing conditions to expected 2025 land use occurred with forest land in the upper watershed being converted to conservative residential [1]. Within HSPF, program modules for pervious land and impervious land are setup with initial values for the water quality parameters and accumulated over the simulation period. This results in predicted loading rates, which are calibrated to match historical observations, leading to final water quality loading rates. The HSPF model land use area is modified to the expected 2025 land use to simulate this difference by remapping the current condition landuse in HSPF to match the St. Tammany land use plan (Table 1). Forested areas of the upper watershed are converted to pervious built up land in the model. The new load rate for each specific land use is re-calculated by the HSPF model. The average annual land use load rate in lbs/acre for $\mathrm{NO}_{3}, \mathrm{PO}_{4}$, and $\mathrm{BOD}$ are exported to be used to populate an average annual load rate table in the GIS (Table 2). The HSPF model's simulated land cover classifications are remapped to match the landuse data of the existing landuse file shown in Table 1.

Table 1. Re-mapping of land use classifications in HSPF model to match the St. Tammany Land Use Plan.

\begin{tabular}{cc}
\hline Existing Landuse Classifications & HSPF Landcover Classifications \\
\hline Open/Forest & Forest \\
Low Density Residential & Urban \\
Municipal/Urban & Urban \\
Commercial & Urban \\
Roads & Urban \\
Coastal Marsh & Wetland \\
Water & Water \\
$\mathrm{Ag} /$ Pasture/Cropland & Barren \\
$\mathrm{Ag} /$ Pasture/Cropland & Agriculture \\
\hline
\end{tabular}

Table 2. Load rate (lb/ac.yr) table created in the project geodatabase.

\begin{tabular}{ccccc}
\hline OBJECTID & Land Cover & $\mathrm{NO}_{3}$ rate & $\mathrm{PO}_{4}$ rate & BOD rate \\
\hline 1 & Open/Forest & 2.39 & 0.09 & 14.27 \\
2 & Low Density Residential & 12.28 & 58.64 & 104.86 \\
3 & Municipal/Urban & 12.28 & 58.64 & 104.86 \\
4 & Coastal Marsh & 2.39 & 0.09 & 14.27 \\
5 & Water & 2.38 & 0.41 & 19.54 \\
6 & Ag/Pasture/Cropland & 40.62 & 0.43 & 84.40 \\
7 & Roads & 12.28 & 58.64 & 104.86 \\
8 & Commercial & 12.28 & 58.64 & 104.86 \\
\hline
\end{tabular}




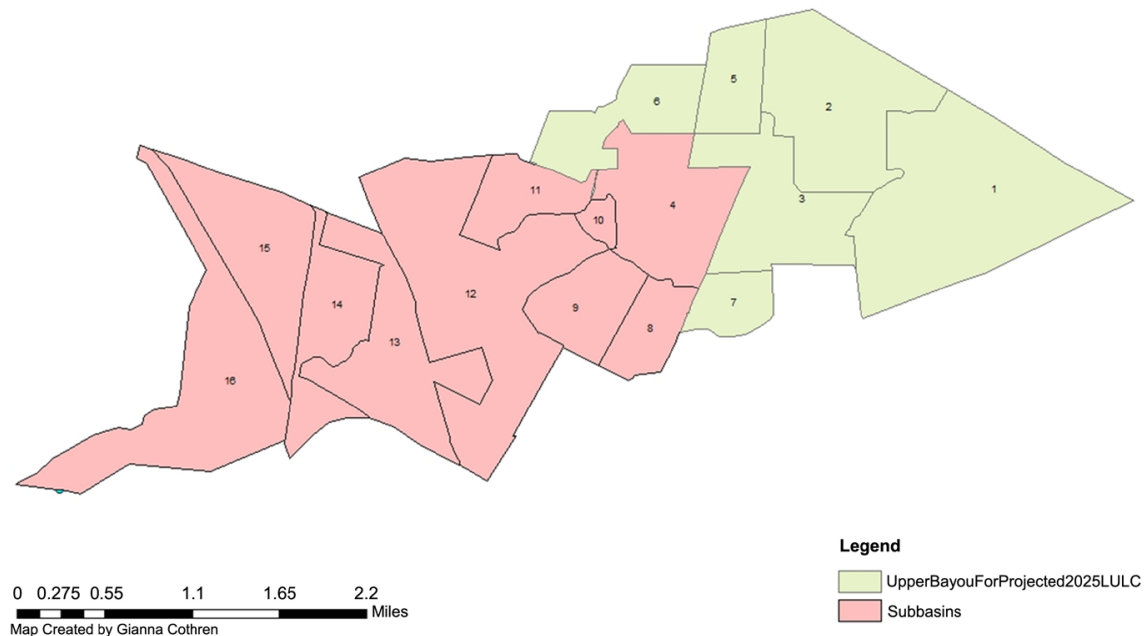

Figure 2. 2025 Projected landuse change in upper Chinchuba watershed.

With ArcCatalog [5], the AvgAnnualLoadperLandCover table is created with $\mathrm{NO}_{3 \_}$rate, $\mathrm{PO}_{4-}$ rate, $\mathrm{BOD} \_$rate, fields using double precision data type. This table is populated with the loading rates using the editor. An intersection of the Chinchuba watershed and existing landuse is performed and three new fields for $\mathrm{NO}_{3}, \mathrm{PO}_{4}$, and BOD load calculation are added. Three fields are added to the intersection table for the $\mathrm{NO}_{3}, \mathrm{PO}_{4}$, and BOD loads. The AvgAnnualLoadperLandCover is joined to the watershed/existing land use Intersection layer using LandCover and Reclassify fields so that the load can be calculated using the subbasin areas and the load rates for each land use in each subbasin. The Field Calculator is used to multiply the load rate by each landuse area divided by the $4046.86 \mathrm{~mm}^{2} / \mathrm{ac}$ conversion to acres resulting in the total load in lbs for each landuse polygon. The final step is to create three copies of the layers to be symbolized for $\mathrm{NO}_{3}, \mathrm{PO}_{4}$, and BOD. Each is then symbolized with quantities using graduated color.

\section{Results and Discussion}

The final results in Figure 3 are created in side-by-side ArcMap layouts [5]. These results depict changes in water quality loads of $\mathrm{NO}_{3}, \mathrm{PO}_{4}$, and $\mathrm{BOD}$ as landuse changes from existing conditions to the future expected 2025 condition in the upper watershed of Bayou Chinchuba. The deeper hues in the upper Chinchuba graphically present the increased loads expected in 2025.

This GIS enhancement of the watershed management plan for St. Tammany parish through display of model results will help parish management official's account for water quality impacts of potential landuse changes. The HSPF (Hydrologic Simulation Program in Fortran) model results are converted with GIS 


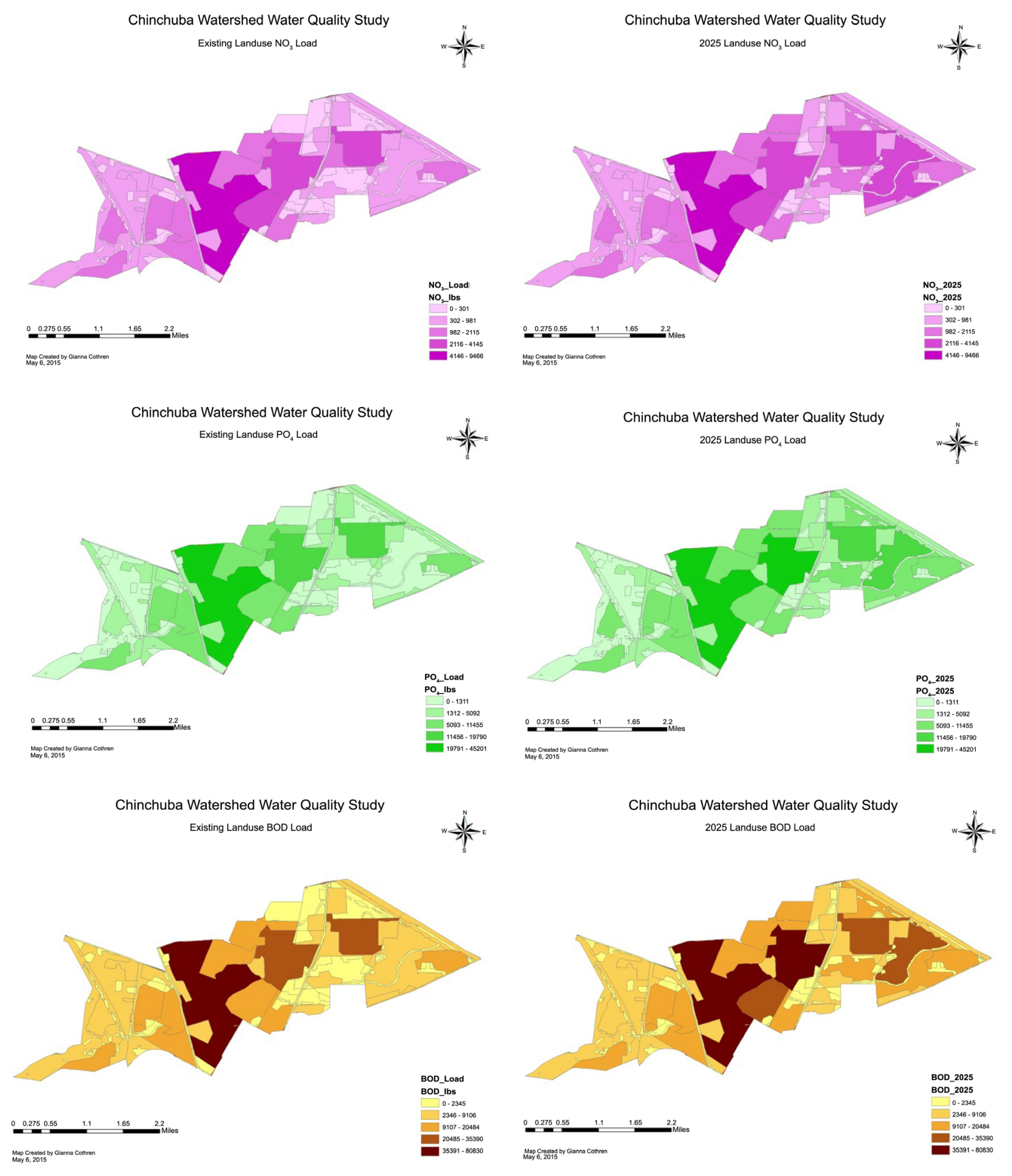

Figure 3. $\mathrm{NO}_{3}, \mathrm{PO}_{4}$, and $\mathrm{BOD}$ simulated load differences from exiting to future conditions.

into a tool that can be used to visualize the impact on water quality with changes in landuse.

\section{Conflicts of Interest}

The author declares no conflicts of interest regarding the publication of this paper. 


\section{References}

[1] Bayou Chinchuba Watershed Management Plan (2006) Buchart Horn, Inc.

[2] Bricknell, B.R., Imhoff, J.C., Kittle, J.L., Donigan, A.S. and Johanson, R.C. (1996) Hydrological Simulation Program-FORTRAN User's Manual for Release 11. U. S. Environmental Protection Agency, Athens.

[3] Better Assessment Science Integrating Point Sources (2001) BASINS Version 3.0 User Manual, United States Environmental Protection Agency, EPA-823-B-01-001, Office of Water, Washington DC.

[4] Environmental Protection Agency (2000) BASINS Technical Note 6: Estimating Hydrology and Hydraulic Parameters for HSPF; EPA 823-R00-0012, U.S. Environmental Protection Agency, Washington DC.

[5] ESRI (2015) ArcGIS Desktop: Release 10.1. Environmental Systems Research Institute, Redlands, CA. 